\title{
HISTOPATHOLOGICAL CHANGES IN ALBINO RATS EXPOSED TO
} METHOMYL

\author{
Mariam M. Morsy ${ }^{*}$, K.A. Gouhar, R.M. Sherif and A.A. Aioub \\ Plant Prot. Dept., Fac. Agric., Zagazig Univ., Egypt
}

\begin{abstract}
The present study was designed to evaluate the toxic effects induced by different time intervals of methomyl exposure on the histological changes in liver, kidneys, lungs and heart of albino rats. Three treatment groups of rats were employed. The $1^{\text {st }}$ group was served as control, while the $2^{\text {nd }}$ and $3^{\text {rd }}$ groups were orally treated with $1 / 10 \mathrm{LD}_{50}\left(3.33 \mathrm{mg}\right.$ a.i. $/ \mathrm{kg}$ b.wt.) and $1 / 20 \mathrm{LD}_{50}(1.66 \mathrm{mg}$ a.i. $/ \mathrm{kg}$ b.wt.) of methomyl, respectively, for five days. The histology of rat liver treated with methomyl 1/10 $\mathrm{LD}_{50}$ showed portal lymphohistiocytic aggregations, proliferative bile ductules, dilated portal, and central vein with widening of hepatic sinusoids, which found in common. Besides, siderocytes were seen accompanying the inflammatory infiltrates with various types of cell injury of the hepatic cells. Focal interstitial and interasinusoidal infiltrations of inflammatory cells mainly lymphohistiocytic cells and hemosiderosis were observed with $1 / 20 \mathrm{LD}_{50}$ and some hepatic cells had acute cell swelling which contains hemosiderosis accompanied hypertrophy of kuffer cells. Histopathological studies showed that degeneration of tubular epithelia were common in kidneys treated with $1 / 10 \mathrm{LD}_{50}$ and some tubules contain hyaline and granular casts, as well as other necrotic tubules were seen with lymphocytic infiltration in the renal cortex. Meanwhile, the results of $1 / 20 \mathrm{LD}_{50}$ treatment showed small focal tubular necrosis or different forms of acute cell swelling and some tubules contain desquamated cells inside its lumen in kidneys. Lungs were thickened with irregular bronchiolar wall due to leukocytic infiltration, peribronchial lymphoid hyperplasia, and desquamated bronchiolar epithelium with $1 / 10 \mathrm{LD}_{50}$ methomyl. Furthermore, focal lymphocytic aggregations replacing the pulmonary tissue with mild perivascular lymphocytic infiltration were observed at same dose. Mild hyperplasia of peribronchial lymphoid tissue including mild thickening of interalveolar septae accompanied with minute perivascular lymphocytic aggregations were the common pulmonary lesions with $1 / 20 \mathrm{LD}_{50}$. The heart had severe dilatation and widening of intramuscular blood vessels with partial hyalinization of some myocardial muscle fibers beside intramuscular edema which treated with $1 / 10 \mathrm{LD}_{50}$. On the other hand, it was normal cardiac muscle and intramuscular blood vessels at 1/20 $\mathrm{LD}_{50}$ treatment. It could be concluded that the $1 / 10 \mathrm{LD}_{50}$ dose of methomyl had a significant histopathological changes in the studied albino rat organs. The pesticide administration caused extensive destruction to the renal tissue. This damage was more pronounced in the higher dose.
\end{abstract}

Key words: Methomyl, histopathology, albino rats, liver, kidneys, lungs, heart, toxicity.

\section{INTRODUCTION}

Pesticides are widely used for agricultural purposes for pest control on field and horticultural crops. The widespread use of pesticides leads to severe environmental pollution and health hazards (Mokhtar et al., 2013).

\footnotetext{
* Corresponding author: Tel. : +2 01159166609

E-mail address: mariam.mosaad@yahoo.com
}

Pesticides have destructive effects on environment if they are drifted outside the area of intentional application, and if they persist in environment longer than necessary. In fact, most of the chemicals that are used as pesticides are not highly selective, but are generally toxic to many non-targeted organisms including human and other desirable forms of life. 
Generally, a great danger on public health of human, which was produced by pesticides, represents alteration in the physiological and biochemistry condition of living organisms. Also, represents some toxic and adverse effects on physiological function of organs, reproductive system and offspring of humans.

Carbamates are mainly used in agriculture as insecticides, fungicides, herbicides, nematicides and plant growth inhibitors. They are also used for industrial and other applications in household products and for the control of vectors in public health. They are among the most extensively used insecticides comprising the third major group of synthetic insecticides being utilized worldwide for agriculture (West and Marnett, 2006).

Methomyl is an oxime carbamate insecticide that controls a broad spectrum of arthropods (Kidd and James, 1991). Methomyl, a systemic and contact poison is used as a broadspectrum insecticide and acaricide. It is widely using throughout the world since it is effective as "contact insecticide" as well as "systemic insecticide". Various commercial preparations of methomyl viz. lannate, methovin, methomex and nudrin are used to control a wide range of insects particularly aphids and lepidoptera, that infest a variety of vegetables, field crops and commercial plantings (Bonatti et al., 1994; Wei et al., 1997). Methomyl acts as a reversible acetyl cholinesterase inhibitor of central nervous system. It is classified as a pesticide of category-1 toxicity and has been accused of causing shortterm adverse health effects (Baron, 1991; WHO, 1996).

The present investigation aimed to study histological changes in some organs of female albino rats after subchronic exposure to the insecticide methomyl.

\section{MATERIALS AND METHODS}

\section{Insecticide Used}

\section{Methomyl (Lannate 90\% SP)}

Chemical name (IUPAC): S-methyl (EZ) $\mathrm{N}$ (methylcarbamoyloxy) thioacetimidate.

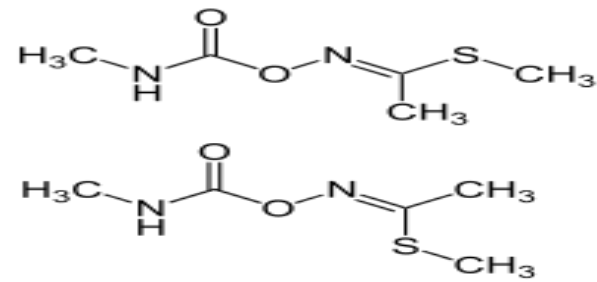

Structural formula: $\mathrm{C}_{5} \mathrm{H}_{10} \mathrm{~N}_{2} \mathrm{O}_{2} \mathrm{~S}$.

\section{Experimental Animal}

Mature albino rats Rattus norvegicus Brok were obtained from the Organization of Serum and Vaccina (Helwan farm). Eighty seven, clinically healthy, mature female rats having an average weight of $170 \pm 10 \mathrm{~g}$ were kept under the normal laboratory conditions in stainless cages for one week at least before being used. The rats were provided with $23 \%$ protein diet and water ad libitum throughout the study.

\section{Experimental Design}

A subchronic toxicity study was designed to investigate histopathological changes in some organs of female albino rats exposed to methomyl.

The rats were divided into three experimental groups as follows:

Group A: rats were kept without any treatments as a normal control. Group B and C: rats were treated with methomyl (90\% SP) at 1/10 (3.33 $\mathrm{mg}$ a.i./.kg b.wt.) and $1 / 20$ of $\mathrm{LD}_{50}(1.66 \mathrm{mg}$ a.i./kg b.wt.), respectively. They were applied orally administration for five times started from the $7^{\text {th }}$ to the $12^{\text {th }}$ days of the gestation period.

The rats were sacrificed and the liver, kidneys, heart and lungs were removed and fixed in $10 \%$ formalin saline.

\section{Histopathological Study}

Routine histopathological procedure was done and stained by Hematoxilen and Eosin stain (H\&E) according to Suvarna et al. (2013). Specimens from the lungs, heart, liver and kidneys of different groups were collected and fixed in $10 \%$ buffered neutral formalin solution, dehydrated in gradual ethanol (70-100\%), cleared in xylene, and embedded in paraffin. Five-micron thick paraffin sections were prepared and then routinely stained and then examined microscopically. 


\section{RESULTS AND DISCUSSION}

\section{Pathological Findings in Liver}

The results of histological study of rat liver are shown in Plates 1, 2, 3, 4 and 5. Microscopically, apparently normal hepatic parenchyma as control group is shown in Plate1. Portal lymphohistiocytic aggregations, proliferative bile ductules, dilated portal, and central vein with widening of hepatic sinusoids were common at methomyl $1 / 10 \mathrm{LD}_{50}$ (3.33 mg a.i./kg b.wt.) (Plates 2 and 3). Siderocytes were seen accompanying the inflammatory infiltrates with various types of cell injury of the hepatic cells. Focal interstitial and interasinusoidal infiltrations of inflammatory cells mainly lymphohistiocytic cells and hemosiderosis were observed with methomyl $1 / 20 \mathrm{LD}_{50}$ (1.66 mg a.i./kg b.wt.) (Plates 4 and 5).

Liver is vulnerable to various environmental toxicants which may cause structural and functional abnormalities (Shyamal et al., 2010). Some hepatic cells had acute cell swelling which contain hemosiderosis accompanied with hypertrophy of kuffer cells. These results were in line with Banerjee et al. (1999) who reported that methomyl exposure promoted oxidative damage of liver cells by enhancing peroxidation of membrane lipids and this might enhance apoptosis. There were also midzonal vacuolar degeneration, necrobiotic changes of hepatocytes and focal areas of necrosis. These lesions were similarly reported in other carbamate toxicities. For example, El-Manakhly (1996) and Muthuviveganandavel et al. (2008) observed degeneration and multiple necrotic areas of hepatocytes infiltrated with mononuclear cells as a result of carbendazim and carbosul-fan treatment in rats, respectively.

\section{Pathological Findings in Kidneys}

Kidneys are responsible for the elimination of metabolic wastes and the control of the amount and composition of the body fluids. Nephrotoxicity can result in systemic toxicity causing: decreased ability to excrete body wastes, inability to maintain body fluid and electrolyte balance and decreased synthesis of essential hormones (e.g., erythropoietin) (Finn, 1977; Laurent et al., 1988).
Microscopically, normal renal tissues are presented in Plate 6 as control group. In rats exposed to methomyl at $1 / 10 \mathrm{LD}_{50}$ value (Plate 7), congested renal blood vessels and glomeruli with preiglomerular lymphocytes and hypercellularity of some glomeruli beside acute cell swelling and degenerated of tubular epithelia were found in common. Some tubules contain hyaline and granular casts as well as other necrotic tubules were seen associated with lymphocytic infiltrations in the renal cortex.

Small focal tubular necrosis or different forms of acute cell swelling and some tubules contain desquamated cells inside its lumen (cellular and hyaline casts) were seen (Plate 8) with methomyl at the $1 / 20 \mathrm{LD}_{50}$. Methomyl administration caused extensive destruction to the renal tissue. This damage was more pronounced in the higher dose, which may cause renal failure (El-Morsy, 2013).

The histological disturbances in the renal tissue in this study come with in accordance with the results obtained from Radad et al. (2009). In the kidneys, methomyl treatment damaged the glomeruli, the tubules and the interstitium. Similarly, Nariman et al. (1995) and Selmanoglu et al. (2001) observed proliferation and swelling of glomerular endothelial cells and tubular degeneration, mononuclear cell infiltration and fibrosis in thiodicarb and carbendazim treated rats, respectively.

\section{Pathological Findings in Lungs}

Apparently normal lung tissues as a control treatment is visualized in Plate 9. Lungs were thickened with irregular bronchiolar wall due to leukocytic infiltration, peribronchial lymphoid hyperplasia and desquamated bronchiolar epithelium were seen at methomyl $1 / 10 \mathrm{LD}_{50}$ (Plate 10). On the other hand, focal lymphocytic aggregations replacing the pulmonary tissue with mild perivascular lymphocytic infiltration were observed as shown in Plate 11. Other bronchioles revealed hyperplastic epithelium and thickened interalveolar septae (Plate 12). The latter due to proliferative pneumoctes and vasculitis with perivascular intense lymphocyte 


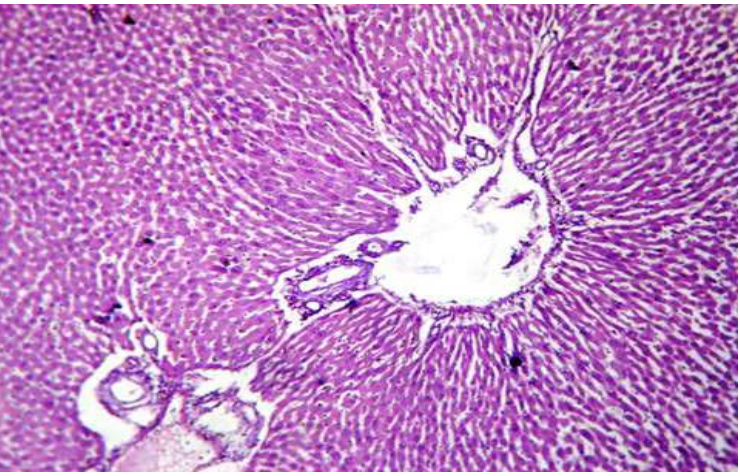

Plate 1. Liver of rat (control) showing normal hepatic parenchyma, $H$ and $E(X 300)$

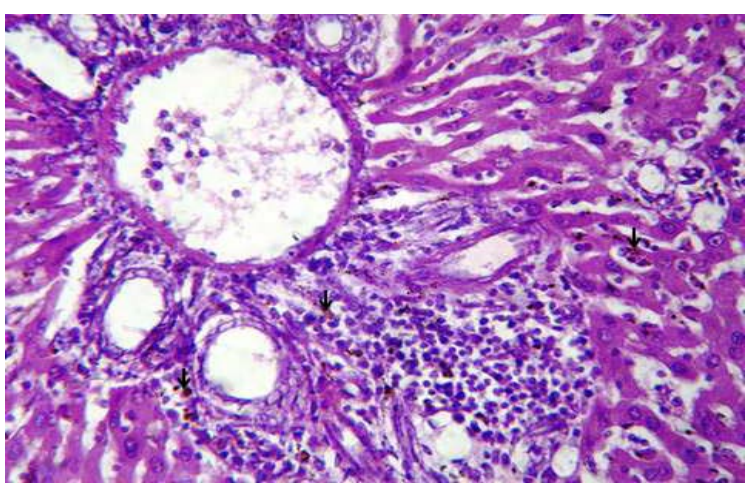

Plate 3. High magnification of the previous picture to show lymphocytes, siderocytes (arrows) and numerous bile ductules with widening of sinusoids, $H$ and $E$ (X 1200)

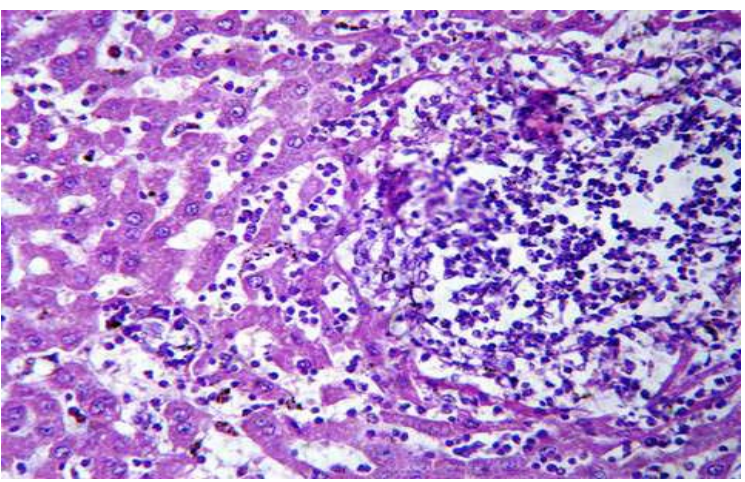

Plate 5. Liver of rat (methomyl $1.66 \mathrm{mg}$ a.i./ kg b.wt.) showing intrasunsoidal lymphocytosis and focal replacement by leukocytic aggregations, $H$ and $E$ (X 1200)

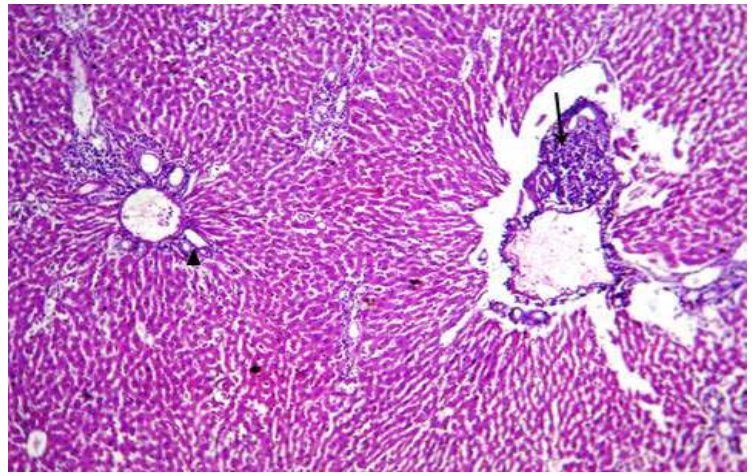

Plate 2. Liver of rat (methomyl $3.33 \mathrm{mg}$ a.i./ kg b.wt.) showing portal lymphocytic aggregations (arrow) and proliferative bile ductules (arrow head), $\mathrm{H}$ and $\mathrm{E}$ (X 300)

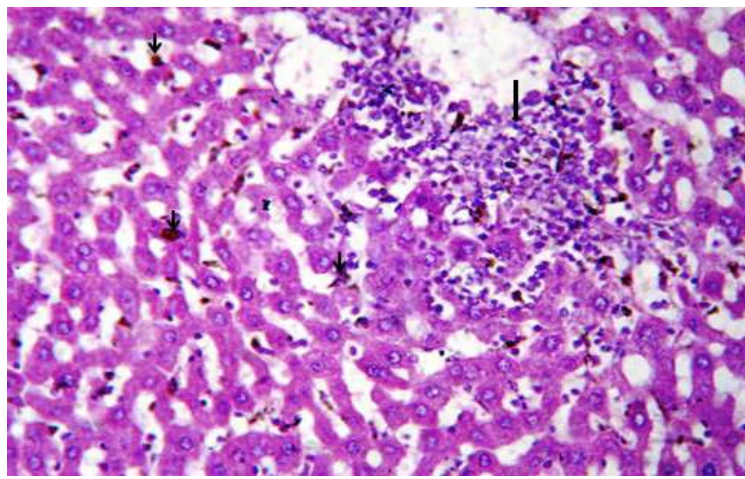

Plate 4. Liver of rat (methomyl $1.66 \mathrm{mg}$ a.i./ kg b.wt.) showing hemosiderosis (thin arrows) and lymphocytic infiltrations (thick arrow), $\mathrm{H}$ and $\mathrm{E}$ (X 1200)

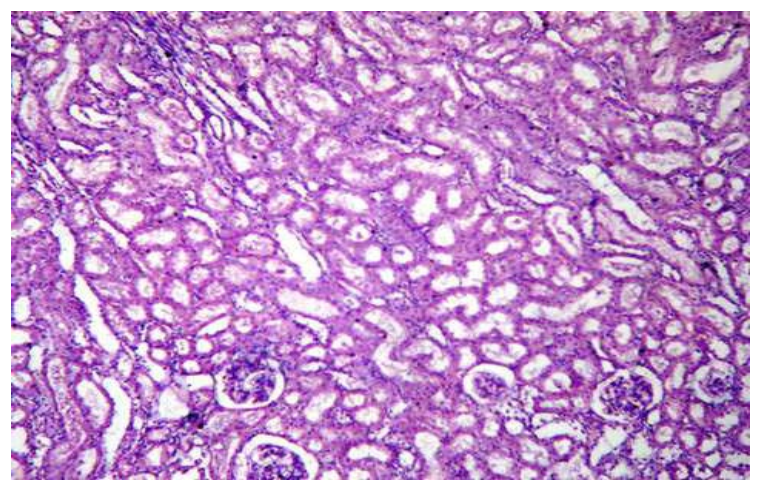

Plate 6. Kidney of rat (control) showing normal renal parenchyma, $H$ and $E$ (X 300) 


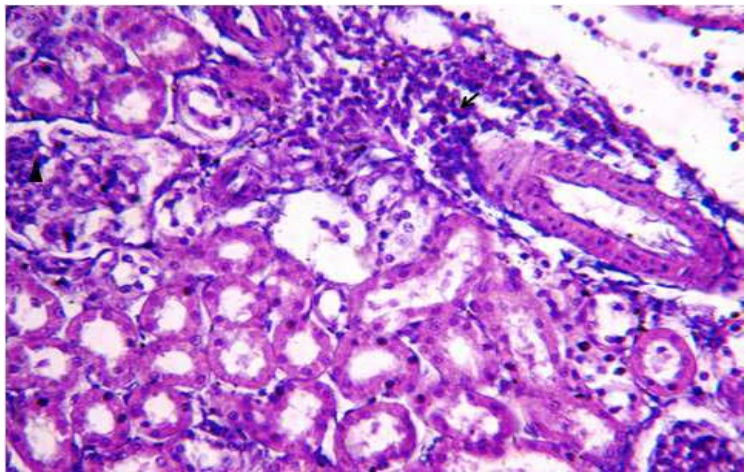

Plate 7. Kidney of rat (methomyl $3.33 \mathrm{mg}$ a.i./ kg b.wt.) showing perivascular lymphocytic aggregations (arrow) and hypercellularity of glomeruli in renal cortex (arrow head), $H$ and $E$ (X 1200)

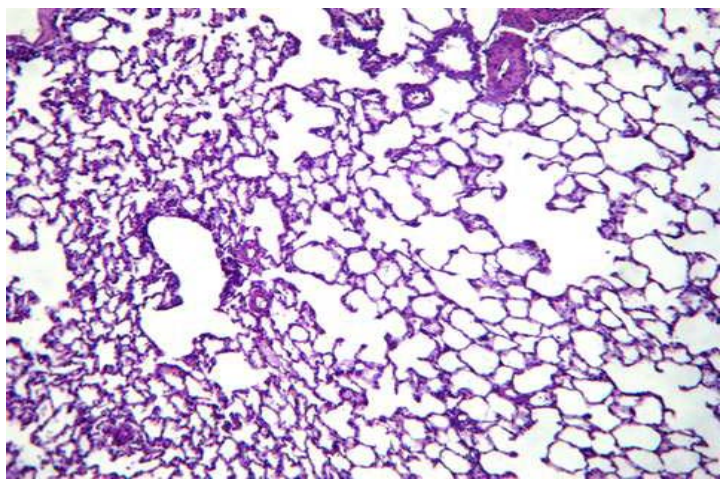

Plate 9. Lung of rat (control) showing normal pulmonary tissue, $H$ and $E$ (X 300)

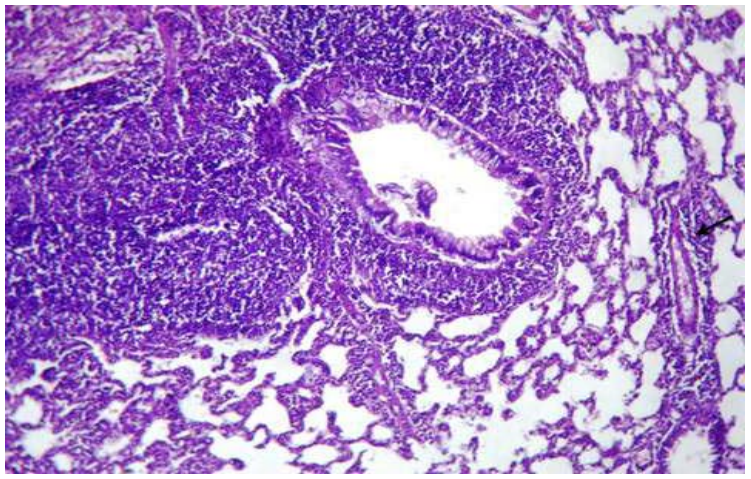

Plate 11. Lung of rat (methomyl $3.33 \mathrm{mg}$ a.i./ kg b.wt.) showing focal lymphocytic aggregations replacing the pulmonary tissue with mild perivascular lymphocytic infiltrations (arrow), $\mathrm{H}$ and $\mathrm{E}$ (X 300)

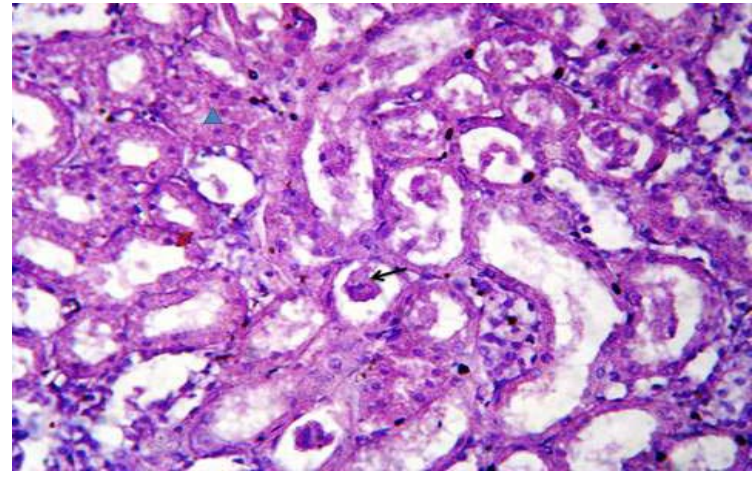

Plate 8. Kidney of rat (methomyl $1.66 \mathrm{mg}$ a.i./ kg b.wt.) showing focal tubular necrosis (arrow head) with cellular casts (arrow), $\mathrm{H}$ and $\mathrm{E}$ (X 1200)

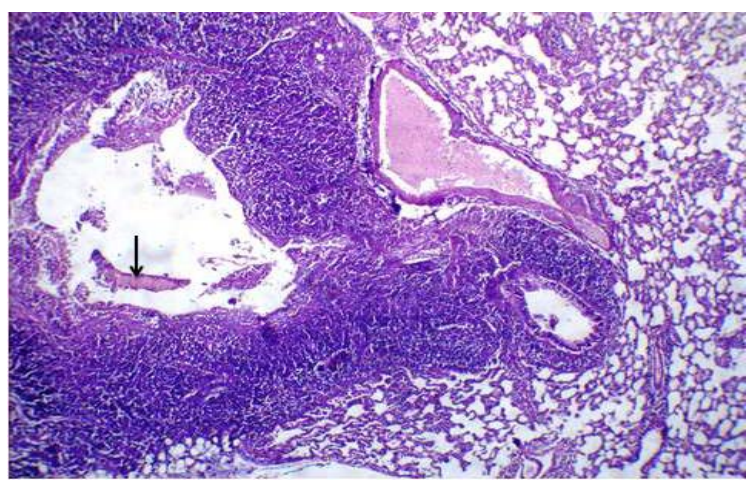

Plate 10. Lung of rat (methomyl $3.33 \mathrm{mg}$ a.i./ kg b.wt.) showing thickened bronchiolar wall by leukocytic infiltration, peribronchial lymphoid hyperplasia and desquamated epithelium (arrow), $H$ and $E$ ( $X$ 120)

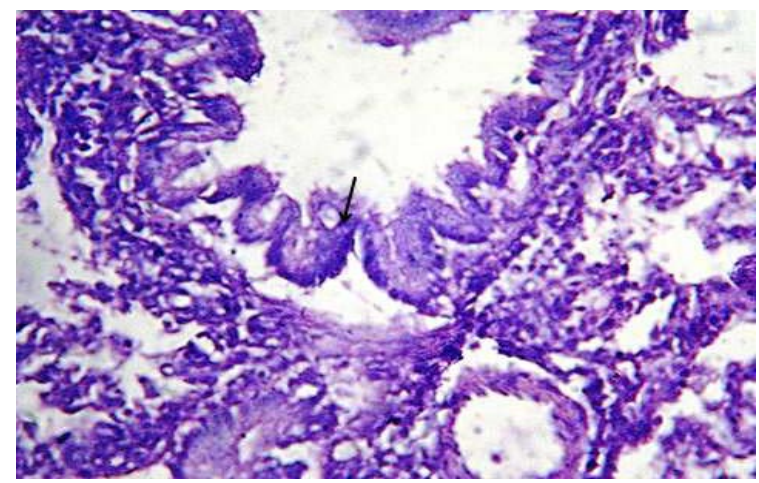

Plate 12. Lung of rat (methomyl $3.33 \mathrm{mg}$ a.i./ kg b.wt.) showing hyperplastic bronchiolar epithelium (arrow) and thickened interalevolar septae, H and $E$ (X 1200) 
aggregations beside focal alveolar emphysema (Plate 13).

In lungs of rats treated with methomyl at the $1 / 20 \quad \mathrm{LD}_{50}$ level, mild hyperplasia of peribronchial lymphoid tissue, with mild thickening of interalveolar septae accompanied with minute perivascular lymphocytic aggregations were the common pulmonary lesions (Plates 14 and 15).

Kidd and James (1991) and El-Khawaga (2005) attributed the pulmonary lesions to the extensive storage of methomyl in the lungs and its excretion in expired air. These effects are the same as those of Bretveld et al. (2007) who reported that exposure to pesticides was a potential risk factor for subfertility. Radad et al. (2009) confirmed that lesions in the lungs consisted of necrosis and sloughing of bronchiolar epithelial lining and lymphocytic perivascualr accumulations. There were also alveolar emphysema, congestion of alveolar capillaries and thickening of alveolar septa as well as haemosiderin laden macrophages in the alveolar walls and lumens.

\section{Pathological Findings in Heart}

Apparently untreated normal cardiac muscles are presented in Plate 16. In rats exposed to methomyl at the $1 / 10 \mathrm{LD}_{50}$ value (Plates 17 and

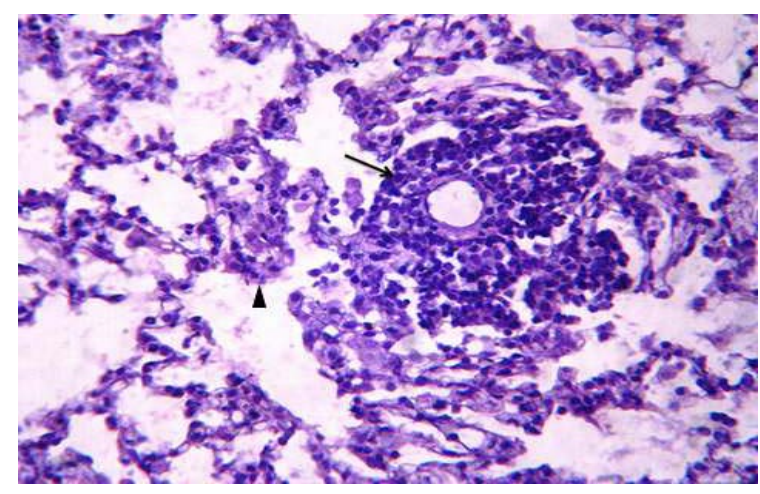

Plate 13. Lung of rat (methomyl $3.33 \mathrm{mg}$ a.i./ kg b.wt.) showing thickened interalveolar tissue by proliferative pneumocytes and lymphocytic infiltrations (arrow head) together with vasculitis and perivascular leukocytic aggregations (arrow) beside focal alveolar emphysema, $H$ and $E$ ( $X$ 1200)
18), severe dilatation and widening of intramuscular blood vessels with partial hyalinization of some myocardial muscle fibers beside intramuscular edema were found. While, normal cardiac muscle and intramuscular blood vessels were obtained with methomyl treatment at the $1 / 20 \mathrm{LD}_{50}$ value.

The extensive use of pesticides is usually accompanied with serious problems of pollution and health hazards. It is now well established that many pesticides in common of use can produce some toxic adverse effect on liver, kidney, lung and heart when tested in variety of experimental animals. Therefore, studying the effect of this widely used pesticide (methomyl) on these aspects has become major health concern. Methomyl exerts its toxic effect via peroxidative damage to the hepatic and renal and induces DNA damage in these organs (El-Khawaga, 2005).

In conclusion, methomyl was found to be potentially toxic to liver, kidneys, lungs, and heart. The observed hepatic, renal, and heart damages could predispose to hepatic insufficiency and renal failure in exposed individuals.

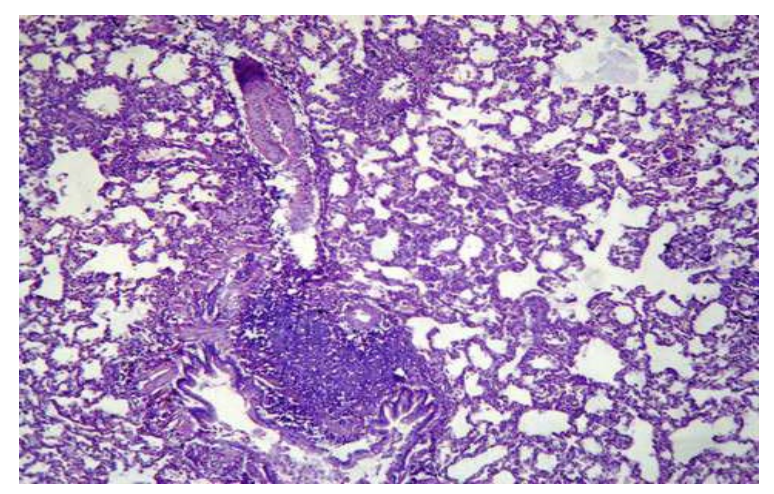

Plate 14. Lung of rat (methomyl $1.66 \mathrm{mg}$ a.i./ $\mathrm{kg}$ b.wt.) showing minute perivascular leukocytic aggregations and mild thickening of interalveolar septae, $\mathrm{H}$ and $E$ (X 300) 


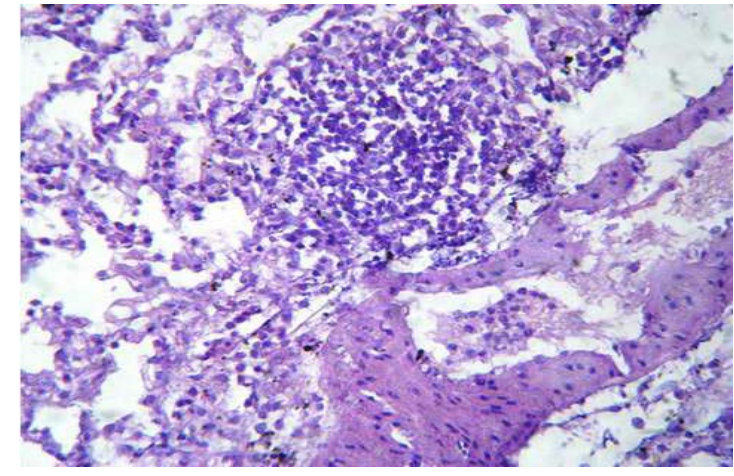

Plate 15. High power of the previous picture to show perivascular lymphohistiocytic aggregations and thickened septae, $H$ and $E$ ( $X$ 1200)

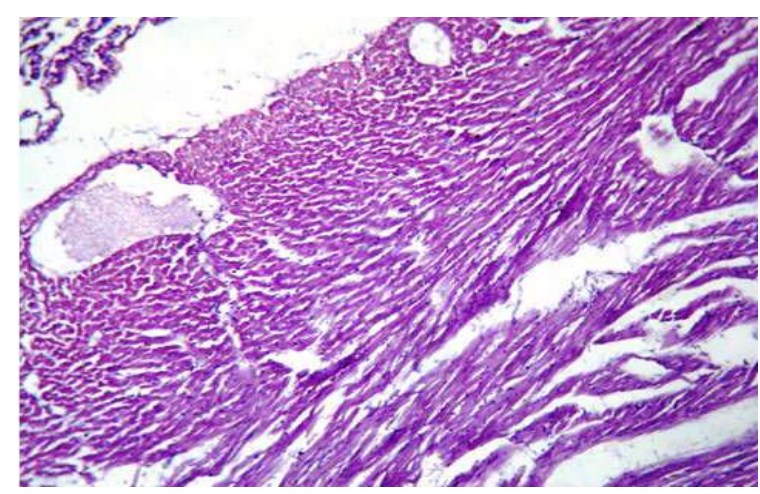

Plate 17. Heart of rat (methomyl $3.33 \mathrm{mg}$ a.i./ $\mathrm{kg}$ b.wt.) showing dilated intramuscular blood vessels and intramuscular edema, $H$ and $E$ ( X 300)

\section{REFERENCES}

Banerjee, B.D., V. Seth, A. Bhattacharya, S.T. Pasha and A.K. Chakraborty (1999). Biochemical effects of some pesticides on lipid peroxidation and free-radical scaven-gers. Toxicol. Letters, 107: 33-47.

Baron, R.L. (1991). Carbamate Insecticides. In: Handbook of Pesticide Toxicology (Eds.: W.J. Jr. Hayes, R.L. Jr. Laws). New York: Academic Press, 3 : 1125-1189.

Bonatti, S., C. Bolognesi, P. Degan and A. Abbondandolo (1994). Genotoxic effects of the carbamate insecticide methomyl, I. In vitro studies with pure compound and the

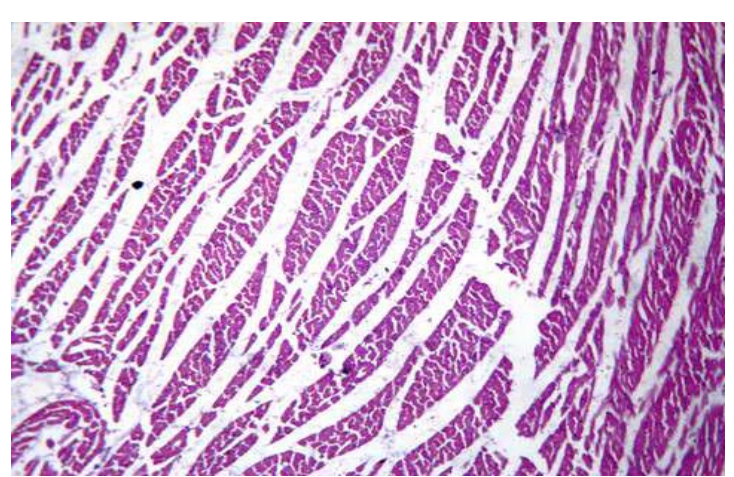

Plate 16. Heart of rat (control) showing normal myocardial tissue, $H$ and $E$ (X 300)

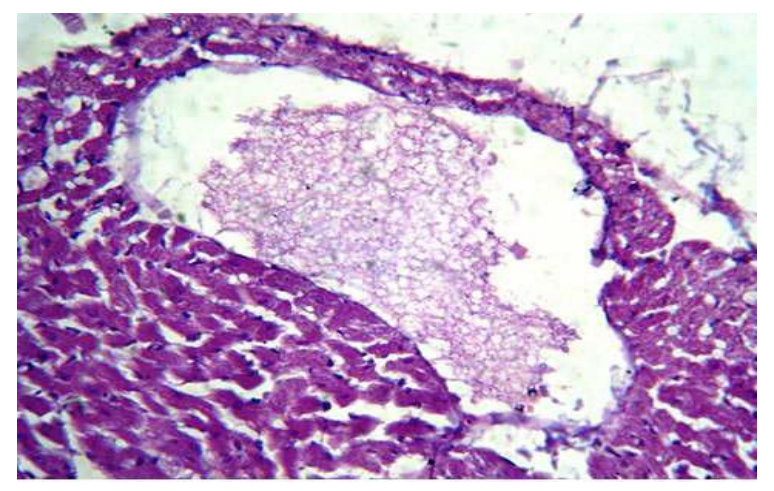

Plate 18. Heart of rat (methomyl $3.33 \mathrm{mg}$ a.i. $/ \mathrm{kg}$ b.wt.) showing dilated intramuscular blood vessels, partial hyalinization and intramuscular edema, $\mathrm{H}$ and $\mathrm{E}(\mathrm{X}$ 1200)

technical formulation "Lannate 25". Environ. Molecular Mutagenesis, 23: 306 -311.

Bretveld, R., M. Brouwers, I. Ebisch and N. Roeleveld (2007). Influence of pesticides on male fertility. Scandinavian J. Work, Environ. and Health, 33: 13-28.

El-Khawaga, O.Y. (2005). Role of selenium on antioxidant capacity in methomyl-treated mice. J. Physiol. and Bioch., 61 : 501-506.

El-Manakhly, E.M. (1996). Therapeutic effect of selenium in rabbits intoxicated with the pesticide carbosulfan: some pathologic and biochemical studies. Egypt. J. Comp. Pathol. and Clin. Pathol., 9: 89-100. 
El-Morsy, A.A. (2013). Could grape seed extract modulates nephritic damage induced by methomex in male rats. Int. J. Latest Res. Sci. and Technol., 2 (5): 26-31.

Finn, W.F. (1977). Renal responses to environmental toxins. Environ. Health Perspect, 20: 15-26.

Kidd, H. and D. James (1991). The Agrochemicals Handbook, $3^{\text {rd }}$ Ed. Royal Soc. Chem. Inform. Serv., Cambridge, England.

Laurent, G., G. Toubeau, J.A. Heuson-Steinnon, P. Tulkens and P. Maldauge (1988). Kidney tissue repair after nephrotoxic injury: biochemical and morphologic characterization. CRC Crit. Rev. Toxicol., 19: 147-183.

Mokhtar, H.I., A. Hasan, H.E. Reda, M.A. Wessam and I.S. Mona (2013). Effect of methomyl on fertility, embryotoxicity and physiological parameters in female rats. J. Appl. Pharm. Sci., 3 (12): 109-119.

Muthuviveganandavel, V., P. Muthuraman, S. Muthu and K. Srikumar (2008). Toxic effects of carbendazim at low dose levels in male rats. J. Toxicol. Sci., 33: 25-30.

Nariman, A.R., A.R. Ahmed, H.M. Amira, M.I. Dessouky (1995). Serum biochemical and histopathological changes associated with repeated exposure of rats to Thiodicarb insecticide. Egypt. J. Comp. Pathol. Clin. Pathol., 8: 79-85.

Radad, K., A. Hashim and M.S.E. Yossef (2009). Histopathological effects of methomyl on Sprague-Dawley rats after repeated application. Bulgarian J. Vet. Med., 12 (2): 149-157.

Selmanoglu, G., N. Barlas, S. Songür and E.A. Koçkaya (2001). Carbendazim induced haematological, biochemical and histopathological changes to the liver and kidney of male rats. Human Exper. Toxicol., 20: 625-630.

Shyamal, S., P.G. Lath, S.R. Suja, V.J. Shine, G.I. Anuja, S. Sini, S. Pradeep, P. Shikha and S. Rajasekharan (2010). Hepatoprotective effect of three herbal extracts on aflatoxin BI- intoxicated rat liver. J. Singapore Med., 5 (4): 326-331.

Suvarna, S.K., C. Layton and J.D. Bancroft (2013). Bancroft's Theory and Practice of Histological Techniques. $7^{\text {th }}$ Ed., Churchill Livingstone, Elsevier, England.

Wei, L., J.S. Chao and C.C. Hong (1997). Assessment of the ability of propuxur, methyomyl and aldicarb, three carbamate insecticides, to induce micronuclei in vitro in cultured Chinese hamster ovary cells and in vivo in BALB/c mice. Environ. Molec. Mutagen., 29: 386-393.

West, J.D. and L.J. Marnett (2006). Endogenous reactive intermediates as modulators of cell signaling and cell death. Chem. Res. Toxicol., 19 : 173- 194.

WHO (1996). World Health Organization. Methomyl. Environmental Health Criteria 178. Geneva, 74. 


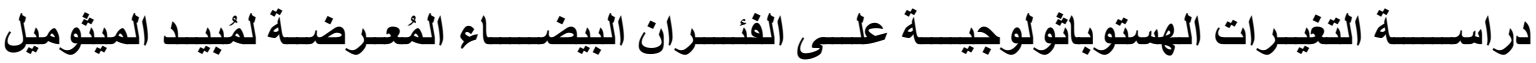

$$
\begin{aligned}
& \text { مريم مسعد مرسي ـ كمال عبدالرازق جوهر - رفعت مصطفى شريف ـ علي أحمد علي أيوب }
\end{aligned}
$$

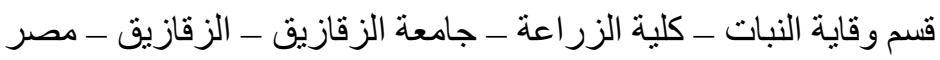

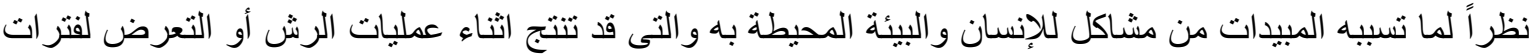

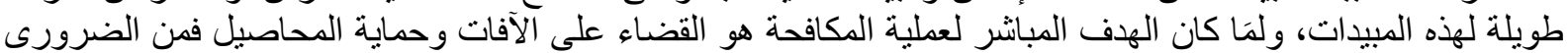

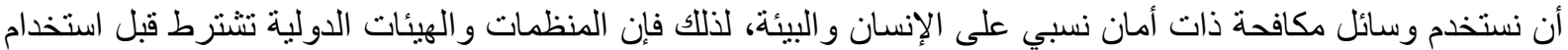

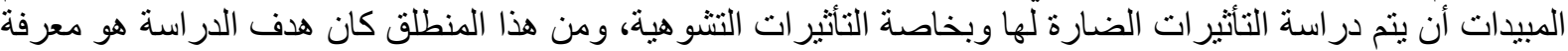

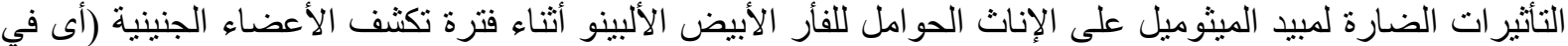

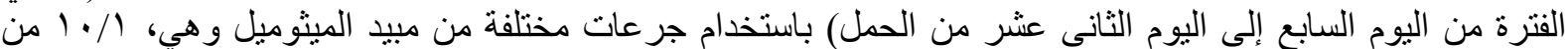

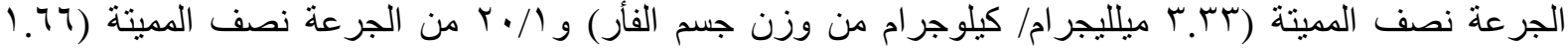

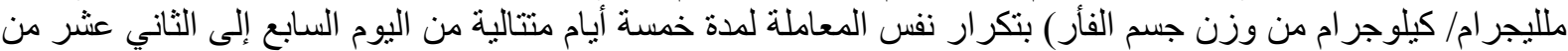

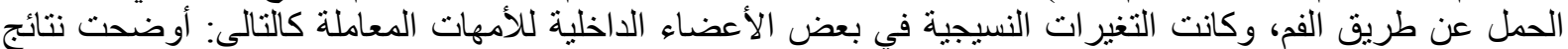

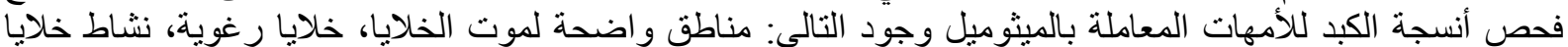
kuffer

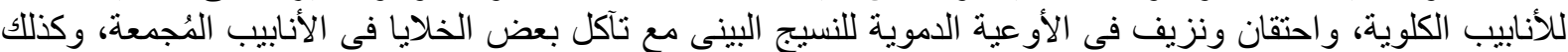

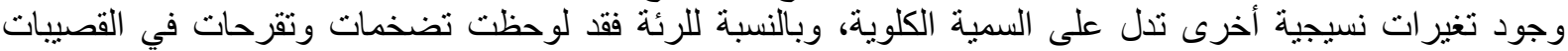

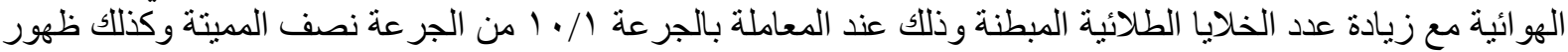

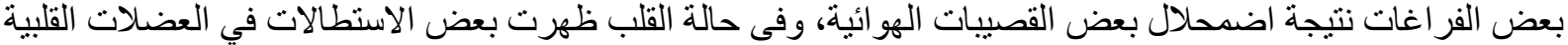

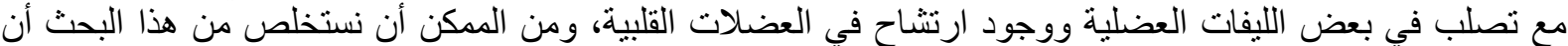

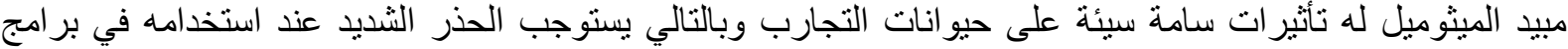
مكافحة الآفات الزراعية، ولات يوصى باستخدامه في حقول محاصيل الخضر و الفاكهة حتى لا تصل متبقيات المبيد إلى في الثي 